\title{
Pengaruh strategi Relating, Experiencing, Applying, Cooperating, Transferring (REACT) berorientasi kearifan lokal terhadap pemecahan masalah dan karakter
}

\author{
Putu Agus Putra Wijaya ${ }^{1 *}$, Gusti Ayu Mahayukti ${ }^{1}$, I Nyoman Gita ${ }^{1}$, Ni Nyoman Parwati ${ }^{1}$ \\ 1 Jurusan Matematika, Universitas Pendidikan Ganesha, Indonesia \\ * Corresponding Author. E-mail: agus.putra.wijaya233@gmail.com
}

\begin{tabular}{ll}
\hline \multicolumn{1}{c}{ ARTICLE INFO } & \multicolumn{1}{c}{ ABSTRACT } \\
\hline Article History: & Penelitian ini bertujuan untuk mendeskripsikan pengaruh pembelajaran matematika dengan \\
Received: 3 July 2019 & strategi pembelajaran Relating, Experiencing, Applying, Cooperating, Transferring (REACT) ber- \\
Revised: 2 Oct. 2019 & orientasi kearifan lokal terhadap kemampuan pemecahan masalah dan karakter positif siswa. \\
Accepted: 28 Dec. 2019 & $\begin{array}{l}\text { Penelitian ini merupakan penelitian mixed method menggunakan concurrent embedded } \\
\text { design. Sampel penelitian yang ditentukan dengan teknik random sampling yaitu siswa SD }\end{array}$ \\
& Negeri 1 Baktiseraga, Bali. Data kuantitatif diperoleh melalui tes kemampuan pemecahan \\
Keywords: & masalah matematika dan data kualitatif diperoleh melalui wawancara, lembar observasi, dan \\
REACT, & angket karakter siswa. Data kuantitatif dianalisis menggunakan uji-t pada taraf signifikansi 5\%. \\
Kearifan lokal, & Data kualitatif terkait karakter siswa disajikan secara deskriptif. Hasil analisis data kuantitatif \\
Pemecahan masalah, & menunjukkan bahwa kemampuan pemecahan masalah matematis siswa yang mengikuti \\
Karakter, & pembelajaran dengan strategi pembelajaran REACT berorientasi kearifan lokal lebih tinggi dari \\
Local wisdom, & pada siswa yang mengikuti pembelajaran konvensional. Hasil analisis data kualitatif menun- \\
Problem-solving, & jukkan bahwa karakter siswa mengalami peningkatan yang tergolong positif setelah mengikuti \\
Character & strategi pembelajaran $R E A C T$ berorientasi kearifan lokal.
\end{tabular}

This study aimed to describe the impact of learning of mathematics with learning strategy of Relating, Experiencing, Applying, Cooperating, Transferring (REACT) oriented to local wisdom on the problem-solving ability and positive character of students. This research was mixedmethod research using a concurrent embedded design. The research sample determined by the random sampling technique was the sixth-grade students of SD Negeri 1 (state primary school) Baktiseraga, Bali, Indonesia. Quantitative data were obtained through tests of mathematical problem-solving ability and qualitative data were obtained through interviews, observation sheets, and student character questionnaires. Quantitative data were analyzed using t-tests at a significance level of 5\%. Qualitative data related to the characters provided descriptively. The results of quantitative data analysis regarding mathematical problem-solving of students who take learning with REACT learning strategy oriented to local wisdom was higher than students who study conventional learning. The results of the qualitative data analysis oppose the increased character of students who were classified as positive after following the REACT learning strategy oriented towards local wisdom.

SCAN ME

This is an open access article under the CC-BY-SA license

\section{How to Cite:}

Wijaya, P. A. P., Mahayukti, G. A., Gita, I. N., \& Parwati, N. N. (2019). Pengaruh strategi Relating, Experiencing, Applying, Cooperating, Transferring (REACT) berorientasi kearifan lokal terhadap pemecahan masalah dan karakter. PYTHAGORAS: Jurnal Pendidikan Matematika, 14(2), 1-5. doi: https://doi.org/10.21831/pg.v14i2.25881

https://doi.org/10.21831/pg.v14i2.25881

\section{PENDAHULUAN}

Perkembangan zaman yang memasuki abad teknologi dan informasi memberikan dampak yang cukup signifikan terhadap perkembangan pendidikan. Dalam beberapa tahun terakhir, dampak negatif dari perkembangan zaman tersebut mulai dirasakan menjangkiti masyarakat di Indonesia khususnya, seperti korupsi, kekerasan, kejahatan, seksual, perusakan, perkelahian massa, dan kehidupan politik yang tidak produktif (Kemendiknas, 
2010). Kebutuhan di era globalisasi semakin kompleks, sehingga tidak menutup kemungkinan permasalahanpermasalahan yang akan dihadapi oleh umat manusia juga semakin kompleks, bahkan sering tidak menentu. Dalam menghadapi situasi demikian, dunia pendidikan diharapkan mampu menyesuaikan kurikulum sehingga adaptif dengan perkembangan zaman. Salah satu upaya pemerintah terkait dengan masalah ini adalah diberlakukannya Kurikulum 2013, yang menekankan pada kompetensi pembentukan sikap, baik sikap sosial maupun sikap spiritual.

Matematika merupakan mata pembelajaran yang wajib didapatkan, karena sudah diberikan mulai dari pendidikan dasar, menengah, hingga perguruan tinggi. Mata pembelajaran matematika perlu diberikan untuk menumbuhkan kemampuan berpikir logis, analitis, sistematis, kritis, kreatif, berinisiatif, dan adaptif terhadap perubahan dan pembangunan. Menurut Suherman (2003, p.15), matematika sangatlah penting dipelajari karena ilmu pengetahuan dan teknologi tidak akan berkembang tanpa adanya kontribusi dari matematika. Mengingat pentingnya peran matematika dalam kehidupan bermasyarakat sehingga penguasaan terhadap matematika harus dipahami dengan tepat dan benar

Undang-Undang RI Nomor 20 Tahun 2003 (Republik Indonesia, 2003) tentang sistem pendidikan nasional, juga menyebutkan bahwa pendidikan nasional berfungsi mengembangkan kemampuan dan membentuk watak serta peradaban bangsa yang martabat dalam rangka mencerdaskan kehidupan bangsa, bertujuan untuk berkembangnya potensi siswa agar menjadi manusia yang beriman dan bertakwa kepada Tuhan Yang Maha Esa, berakhlak mulia, sehat, berilmu, cakap, kreatif, mandiri dan menjadi warga negara yang demokratis serta bertanggung jawab. Dengan demikian tujuan pembelajaran matematika juga harus selaras dengan tujuan pendidikan nasional tersebut, termasuk berperan dalam menangkal dampak negatif dari perkembangan teknologi dan informasi.

Lembaga-lembaga pendidikan memegang peranan utama dalam mencegah dampak negatif yang ditimbulkan dari perkembangan teknologi dan informasi tersebut, dengan mengupayakan pembentukan generasi yang cerdas secara intelektual dan memiliki karakter yang baik sesuai dengan nilai-nilai karakter bangsa (Parwati, 2014). Oleh karena itu, sangat besar harapan dari seluruh insan bangsa kita untuk bisa kembali menerapkan nilai-nilai luhur karakter bangsa Indonesia. Beberapa penelitian (misalnya: Pattaro, 2016; Sanderse, 2013; Zurqoni, Retnawati, Arlinwibowo, \& Apino, 2018; Zurqoni, Retnawati, Apino, \& Anazifa, 2018) telah melaporkan akan pentingnya pendidikan karakter sebagai bekal menghadapi tantangan global yang semakin kompleks.

Sejalan dengan hal tersebut, Program Nawacita Presiden Republik Indonesia ke 7 Joko Widodo, menghendaki adanya penguatan karakter siswa melalui harmonisasi olah hati (etik), olah rasa (estetis), olah pikir (literasi), dan olah raga (kinestetik), yang selanjutnya disebut dengan Penguatan Pendidikan Karakter (PPK) (Kemendikbud, 2017). PPK tersebut tertuang dalam Peraturan Presiden Nomor 87 Tahun 2017 tentang Penguatan Pendidikan Karakter yang dilaksanakan dengan menerapkan nilai-nilai Pancasila dalam pendidikan karakter yang merujuk pada lima nilai utama yang meliputi religius, nasionalis, mandiri, gotong royong, dan integritas (Presiden, 2017). Hal tersebut tentunya perlu diselaraskan dengan tujuan pembelajaran matematika.

Tujuan pembelajaran matematika di Indonesia yang tercantum di dalam standar isi untuk satuan pendidikan dasar dan menengah (BSNP, 2013) diantaranya melatihkan dan mengembangkan berbagai kemampuan, seperti kemampuan berpikir kritis dan memecahkan masalah, kemampuan berkomunikasi dan bekerja sama, kemampuan mencipta dan membaharui, literasi teknologi informasi dan komunikasi, kemampuan belajar kontekstual, serta kemampuan mengolah informasi dan literasi media. Hal tersebut sejalan dengan lima standar proses dalam pembelajaran matematika menurut NCTM (2000) yaitu problem-solving (pemecahan masalah), reasoning and prove (bernalar dan membuktikan), communication (komunikasi), connection (mengaitkan), dan representation (representasi). Dengan demikian kemampuan pemecahan masalah merupakan salah satu bagian penting dalam pembelajaran matematika.

Pentingnya kemampuan pemecahan masalah adalah karena kemampuan tersebut merupakan bagian integral dari matematika, sehingga tidak bisa dipisahkan dari pembelajaran matematika. Menurut Polya pemecahan masalah merupakan suatu usaha mencari jalan keluar dari suatu kesulitan guna mencapai suatu tujuan yang tidak dengan segera dapat dicapai (Hudojo, 2003). Selain itu, menurut Kostousov dan Kudryavtsev (2017) pendidikan sebaiknya membekali siswa tidak hanya pada aspek pengetahuan, melainkan untuk mempersiapkan mereka dalam memecahkan masalah di kehidupan nyata. Pemecahan masalah juga dapat melatih siswa untuk membuat keputusan tentang bagaimana mencari solusi dari permasalahan yang dihadapi dan memperoleh kepercayaan diri atas tindakan yang diambil (Lahinda \& Jailani, 2015) 
Penelitian terkait pemecahan masalah telah banyak dilakukan (misalnya: Kawiyah, 2015; Lahinda \& Jailani, 2015; Samo, 2017; Sudiarta, 2008). Secara umum penelitian tersebut merekomendasikan bahwa kemampuan pemecahan masalah siswa di Indonesia masih perlu ditingkatkan. Sudiarta (2008) menemukan bahwa dari 72 orang guru responden pengajar matematika di Sekolah Dasar (SD) yang berasal dari 26 SD yang di samping dari 1036 SD di Provinsi Bali, 89\% mengatakan bahwa, siswa mengalami kesulitan dalam memecahkan masalah. Dari penelitian tersebut terungkap bahwa faktor utama yang menjadi penyebab rendahnya kemampuan pemecahan masalah matematika siswa, yaitu pembelajaran yang dilaksanakan selama ini belum mampu mengembangkan kemampuan mengkomunikasikan ide-ide matematika siswa secara tepat, mengambangkan kemampuan pemahaman konsep matematika siswa dan mengembangkan kemampuan pemecahan masalah matematika siswa. Hal ini, sesuai dengan apa yang dikemukakan Budhayanti, Baskoro, Roostanto, dan Simanullang (2008, p.11), bahwa pemecahan masalah merupakan salah satu topik yang penting dalam mempelajari matematika. Dikatakan penting karena pemecahan masalah matematika sangat berhubungan dengan kehidupan sehari-hari.

Mengingat pentingnya pemecahan masalah dalam pembelajaran matematika, maka diperlukan strategi pembelajaran yang dapat memfasilitasi hal tersebut, sekaligus membentuk karakter positif siswa. Salah satu strategi pembelajaran yang direkomendasikan untuk tujuan tersebut yaitu strategi pembelajaran Relating, Experiencing, Applying, Cooperating, Transfering atau disingkat REACT. Menurut Marlissa dan Widjanjanti (2015) melalui strategi pembelajaran REACT selain untuk meningkatkan kemampuan pemecahan masalah, secara tidak langsung juga akan berdampak pada meningkatkan karakter siswa. Melalui pembelajaran REACT siswa akan terlatih untuk menjadi pribadi yang bertanggung jawab, jujur dan disiplin dalam menyelesaikan permasalahan. Ultay (2012) mengemukakan terdapat beberapa kelebihan pembelajaran REACT, diantaranya keterlibatan siswa secara aktif dalam tugas yang mengarah pada kesimpulan, aktivitas kognitif didorong melalui kerja tim dan demonstrasi, melatih keterampilan mengamati dalam pembelajaran dan koneksi ke konsep yang dipelajari, penerapan pengetahuan baru diikuti dengan umpan balik, dan integrasi data baru dengan keterampilan hidup sehari-hari dan demonstrasi pengetahuan baru.

Dalam rangka memantapkan karakter siswa, maka strategi pembelajaran REACT dapat diintegrasikan dengan pendidikan karakter. Salah satu prinsip dari pendidikan karakter dalam PPK adalah kearifan lokal. Kearifan lokal masyarakat, khususnya masyarakat Bali memiliki nilai-nilai karakter yang dijadikan sebagai pedoman masyarakat untuk melangsungkan kehidupan. Melalui motivasi dan pesan-pesan kehidupan yang ada dalam kearifan lokal tersebut, kemudian disampaikan pada proses pembelajaran, maka hal tersebut bisa menumbuh kembangkan nilai karakter dalam diri siswa. Oleh sebab itu, strategi pembelajaran REACT hendaknya diintegrasikan dengan nilai karakter berbasis kearifan lokal.

Strategi pembelajaran REACT terdiri dari lima langkah yaitu: relating (mengaitkan), experiencing (mengalami), applying (menerapkan), cooperating (kerjasama), dan transferring (menggunakan pengetahuan dalam konteks baru atau situasi baru) (James, 2015). Strategi ini sangat cocok diterapkan dalam pembelajaran matematika (Hasanah, Buchori, Prasetyowati, \& Nursyahidah, 2019; Putri, Mardiyana, \& Saputro, 2019) dan berpengaruh terhadap kemampuan pemecahan masalah serta dampaknya terhadap karakter positif siswa. Strategi pembelajaran REACT berorientasi kearifan lokal dapat dilaksanakan dengan memberikan permasalahan yang harus dicari solusinya kemudian di dalamnya diintegrasikan dengan nilai-nilai kearifan lokal. Dengan demikian nilai-nilai kearifan lokal dapat diintegrasikan pada langkah-langkah pembelajaran REACT, sebagaimana dijelaskan pada paragraf selanjutnya.

Langkah pertama yaitu relating, yaitu menghubungkan konsep baru dengan sesuatu yang sudah diketahui siswa, atau menghubungkan yang sudah diketahui dengan informasi baru. Dalam hal ini guru dapat menampilkan permasalahan kemudian mengarahkan siswa dengan mengajukan beberapa pertanyaan untuk memudahkan siswa dalam memahami masalah, dan kemudian disisipi motivasi kearifan lokal agar siswa menyadari dirinya memiliki tanggung jawab. Langkah kedua yaitu experiencing, yaitu memberikan pengalaman langsung kepada siswa melalui eksplorasi dan penemuan. Dengan pengalaman, siswa mengembangkan kemampuan untuk memahami konsep-konsep abstrak, manipulasi simbol dan menggeneralisasi permasalahan (AAAS, 1990). Guru membimbing dalam kegiatan eksplorasi dan penemuan, serta disisipi motivasi kearifan lokal agar siswa menyelesaikan masalah secara optimal serta sikap yang menjadi teladan. Langkah relating dan experiencing dapat meningkatkan kemampuan siswa dalam belajar konsep-konsep baru.

Langkah applying, yaitu menerapkan konsep dalam pembelajaran kontekstual, sehingga dapat mengembangkan wawasan, makna yang dirasakan, dan pemahaman (Crawford, 2001). Guru memfasilitasi siswa jika 
menemukan kesulitan saat menerapkan konsep yang dipelajari dalam merencanakan penyelesaian. Langkah cooperating yaitu bersama kelompok menyelesaikan permasalah kontekstual yang diberikan. Selama kegiatan ini berlangsung, guru mengawasi, berkeliling mengecek dan membimbing pada pembelajaran berkelompok, serta disisipkan nilai kearifan lokal agar siswa terbiasa bekerja sama dan bersikap jujur terhadap siswa lainnya. Terakhir, langkah transferring yaitu menggunakan pengetahuan dalam konteks baru atau situasi baru. Tahap ini bertujuan untuk melatih siswa berpikir kritis dan kreatif dengan tetap memperhatikan unsur kearifan lokal, sehingga siswa dapat menyelesaikan masalah secara optimal serta memiliki sikap untuk menjadi teladan.

Berdasarkan uraian yang telah dikemukakan, salah satu upaya yang dapat dilakukan untuk meningkatkan kemampuan pemecahan masalah sekaligus karakter siswa yaitu dengan menerapkan pembelajaran REACT yang berorientasi pada kearifan lokal. Sehubungan dengan itu, maka penelitian ini bertujuan untuk mendeskripsikan pengaruh pembelajaran matematika dengan strategi pembelajaran REACT berorientasi kearifan lokal terhadap kemampuan pemecahan masalah dan karakter positif siswa pada jenjang sekolah dasar.

\section{METODE}

Jenis penelitian ini merupakan penelitian kombinasi (mixed methods). Menurut Sugiyono (2017) metode penelitian kombinasi (mixed methods) adalah suatu metode penelitian yang mengkombinasikan metode kuantitatif dan kualitatif yang digunakan secara bersamaan dalam suatu kegiatan penelitian, sehingga diperoleh data yang lebih komprehensif, valid, reliabel dan obyektif. Penelitian kombinasi menggunakan desain concurrent embedded design. Menurut Creswell (2010) concurrent embedded design adalah untuk mengumpulkan data kuantitatif dan kualitatif dalam waktu yang bersamaan atau dalam waktu yang berurutan. Penelitian kuantitatif dilakukan dengan desain eksperimen semu (quasi experiment). Penelitian eksperimen ini dapat digunakan untuk melihat pengaruh yang ditimbulkan dan faktor-faktor penyebab dari perlakukan berbeda yang diberikan pada masing-masing kelompok, dimana peneliti tidak dapat mengontrol semua variabel dan kondisi secara ketat (Sugiyono, 2017). Penelitian eksperimen tersebut bertujuan untuk menyelidiki pengaruh strategi pembelajaran REACT terhadap kemampuan pemecahan masalah matematis siswa. Penelitian kualitatif dilakukan untuk mendeskripsikan pengaruh strategi pembelajaran REACT terhadap karakter siswa.

Subjek penelitian adalah siswa kelas VI SD Negeri 1 Baktiseraga, Kabupaten Buleleng, Bali. Dua kelas dipilih secara acak untuk menentukan kelompok eksperimen dan kelompok kontrol. Sebelum menentukan kelompok eksperimen dan kelompok kontrol, dilakukan uji kesetaraan terhadap kedua kelas tersebut dengan menggunakan uji-t degan menggunakan data nilai ulangan akhir semester ganjil tahun ajaran 2018/2019 kelas V SD Negeri 1 Baktiseraga. Hasil uji kesetaraan tersebut menunjukkan bahwa kedua kelas tersebut setara. Langkah selanjutnya yaitu dilakukan pengundian untuk menentukan kelompok eksperimen dan kelompok kontrol. Dari hasil pengundian diperoleh kelas $V$ B sebagai kelompok eksperimen dan kelas $\vee$ A sebagai kelompok kontrol. Kelompok eksperimen memperoleh perlakuan dengan strategi pembelajaran REACT berorientasi kearifan lokal, sedangkan kelompok kontrol memperoleh perlakuan dengan pembelajaran konvensional yaitu ekspositori.

Variabel bebas dalam penelitian ini adalah strategi pembelajaran, dengan variasi strategi pembelajaran REACT berorientasi kearifan lokal yang diterapkan pada kelompok eksperimen dan pembelajaran konvensional yang diterapkan pada kelompok kontrol. Sedangkan variabel terikat dalam penelitian ini adalah kemampuan pemecahan masalah matematika serta dampaknya terhadap karakter positif siswa. Untuk penelitian eksperimen, desain yang digunakan adalah post test only control group design, seperti dapat dilihat pada Tabel 1.

Tabel 1. Desain Penelitian Eksperimen

\begin{tabular}{lcc}
\hline Kelompok & Perlakukan & Post-test \\
\hline Eksperimen & $\mathrm{X}$ & $\mathrm{Y}_{1}$ \\
Kontrol & - & $\mathrm{Y}_{2}$ \\
\hline
\end{tabular}

Keterangan:

$X$ = Perlakuan berupa penerapan strategi pembelajaran REACT berorientasi kearifan lokal.

$\mathrm{Y}_{1}=$ Skor post-test kemampuan pemecahan masalah untuk kelas eksperimen

$\mathrm{Y}_{2}=$ Skor post-test kemampuan pemecahan masalah untuk kelas kontrol

Data yang dikumpulkan dalam penelitian ini meliputi data kuantitatif dan data kualitatif. Data kuantitatif diperoleh melalui tes kemampuan pemecahan masalah matematika dan data kualitatif diperoleh melalui 
wawancara, lembar observasi, dan angket karakter siswa. Agar instrumen yang telah disusun layak dipergunakan dalam penelitian, maka instrumen terlebih dahulu divalidasi. Validitas isi instrumen diuji menggunakan formula Gregory dengan melibatkan dua orang pakar dan diperoleh indeks validitas isi sebesar 1,00 yang menunjukkan bahwa instrumen penelitian memiliki angka validitas isi sangat tinggi, atau dengan kata lain instrumen sangat relevan untuk digunakan. Untuk mencari koefisien validitas alat evaluasi yang berbentuk soal uraian digunakan rumus koefisien korelasi product-moment Karl Pearson (Candiasa, 2010). Sedangkan untuk estimasi reliabilitasnya digunakan formula Alpha Cronbach (Candiasa, 2010) dan diperoleh koefisien reliabilitas sebesar 0,636 yang termasuk dalam kategori tinggi.

Sebelum melakukan analisis data kuantitatif, maka data yang diperoleh diuji terlebih dahulu normalitas dan homogenitasnya. Uji normalitas sebaran data dilakukan dengan menggunakan uji Lilliefors. Adapun kriteria pengambilan keputusan $L_{\text {hitung }}<L_{\text {tabel }}$ maka $H_{0}$ diterima menyatakan bahwa data berasal dari populasi yang berdistribusi normal. Uji homogenitas dilakukan untuk membuktikan bahwa sampel memiliki varians yang homogen. Pengujian homogenitas pada penelitian ini menggunakan uji Levene. Adapun kriteria pengambilan keputusan $W<$ $F_{\text {tabel }}$ maka $H_{0}$ diterima menyatakan bahwa data berasal dari populasi yang memiliki varians yang homogen. Pengujian hipotesis menggunakan uji-t satu arah (one-tailed) pada taraf signifikan $5 \%$. Adapun analisis data kualitatif pada penelitian menggunakan langkah-langkah analisis Miles, Huberman, dan Saldana (2014) yaitu: reduksi data, penyajian data, dan verifikasi data.

\section{HASIL DAN PEMBAHASAN}

Rangkuman data kemampuan pemecahan masalah matematis siswa pada kelompok eksperimen dan kontrol dapat dilihat pada Tabel 2.

Tabel 2. Deskripsi Kemampuan Pemecahan Masalah Matematis Siswa

\begin{tabular}{lcc}
\hline \multirow{2}{*}{ Statistik } & \multicolumn{2}{c}{ Kelompok } \\
\cline { 2 - 3 } & Eksperimen & Kontrol \\
\hline$N$ & 28 & 28 \\
Rata-rata & 11,46 & 9,21 \\
Simpangan baku & 3,46 & 2,47 \\
\hline
\end{tabular}

Berdasarkan Tabel 2 terlihat bahwa rata-rata nilai kemampuan pemecahan masalah matematis siswa yang mengikuti strategi pembelajaran REACT berorientasi kearifan lokal pada kelompok eksperimen lebih tinggi dari pada ratarata nilai kemampuan pemecahan masalah matematika siswa pada kelompok kontrol yang mengikuti pembelajaran konvensional. Dengan demikian, secara deskriptif terlihat bahwa capaian hasil belajar siswa dengan strategi pembelajaran REACT berorientasi kearifan lokal lebih baik dari pada capaian hasil belajar siswa dengan pembelajaran konvensional.

Sebelum uji hipotesis dilakukan, terlebih dahulu dilakukan pengujian prasyarat, yaitu uji normalitas dan homogenitas varians pada data kemampuan pemecahan masalah matematika siswa. Hasil uji normalitas data kemampuan pemecahan masalah matematis siswa pada kelas eksperimen diperoleh $L_{\text {hitung }}=0,155<L_{\text {tabel }}=0,250$ (untuk $N$ = 28 pada taraf signifikansi 5\%), maka $H_{0}$ diterima yang berarti data skor tes kemampuan pemecahan masalah matematis kelas eksperimen berasal dari populasi yang berdistribusi normal. Pada kelompok kontrol diperoleh $L_{\text {hitung }}=0,136<L_{\text {tabel }}=0,250$ (untuk $n=28$ pada taraf signifikansi $5 \%$ ), maka $H_{0}$ diterima yang berarti data skor tes kemampuan pemecahan masalah matematis kelas kontrol berasal dari populasi yang berdistribusi normal. Uji homogenitas varians dilakukan dengan uji Levene. Berdasarkan hasil perhitungan diperoleh bahwa nilai $W=0,728$ dan nilai $F_{\text {tabel }}=4,020$. Apabila dibandingkan, nilai $W<F_{\text {tabel }}$ sehingga $H_{0}$ diterima dan hal tersebut berarti skor tes kemampuan pemecahan masalah matematis siswa kelas eksperimen dan kelas kontrol memiliki varians yang homogen.

Hasil uji normalitas dan homogenitas varians menunjukkan bahwa data kemampuan pemecahan masalah matematis siswa untuk kelas eksperimen dan kelas kontrol berdistribusi normal dan memiliki varians yang homogen. Dengan demikian, pengujian hipotesis dapat dilakukan dengan menggunakan uji-t satu arah (one-taied) dengan taraf signifikan $5 \%(\alpha=0,05)$. Adapun hipotesis yang hendak diuji adalah kemampuan pemecahan masalah matematis siswa dengan strategi REACT berorientasi kearifan loak lebih baik dari pada kemampuan pemecahan 
PYTHAGORAS: Jurnal Pendidikan Matematika, 14 (2), 2019 - 183

Putu Agus Putra Wijaya, Gusti Ayu Mahayukti, I Nyoman Gita, Ni Nyoman Parwati

masalah matematis siswa dengan pembelajaran konvensional. Rangkuman hasil pengujian hipotesis tersebut disajikan pada Tabel 3.

Tabel 3. Hasil Indepent Sample t Test

\begin{tabular}{lr}
\hline Statistik & Nilai \\
\hline$t$ & $-2,746$ \\
$d f$ & 54 \\
Sig. (2-tailed) & 0,008 \\
Mean Difference & $-2,250$ \\
Std. Error Difference & 0,819 \\
\hline
\end{tabular}

Hasil uji statistik pada Tabel 3 menunjukkan bahwa nilai sig. yaitu 0,008 (two-tailed), sehingga nilai sig. untuk uji satu arah (one-tailed) adalah 0,008/2 =0,004, sehingga $\mathrm{H}_{0}$ ditolak. Dengan demikian, dapat disimpulkan bahwa kemampuan pemecahan masalah matematis siswa kelas V SD Negeri 1 Baktiseraga dengan strategi pembelajaran REACT berorientasi kearifan lokal lebih tinggi dari pada kemampuan pemecahan masalah matematis siswa dengan pembelajaran konvensional.

Data selanjutnya yaitu deskripsi hasil angket karakter siswa setelah dilakukan perlakukan seperti disajikan pada Tabel 4. Data pada Tabel 4 menunjukkan bahwa secara umum, baik pada kelas eksperimen maupun kontrol, karakter siswa berada pada kategori yang memuaskan. Namun, pada kelas konvensional masih terdapat 10,71\% siswa yang memiliki karakter pada kategori cukup. Sedangkan pada kelas eksperimen karakter semua siswa telah berada pada kategori baik hingga sangat baik. Perbandingan jumlah siswa yang memiliki karakter sangat baik antara kelas eksperimen dan kontrol juga cukup mencolok. Hal ini menunjukkan bahwa strategi pembelajaran REACT berorientasi kearifan lokal yang diterapkan pada kelas eksperimen memberikan kontribusi yang lebih baik terhadap perkembangan karakter siswa, dibandingkan dengan pembelajaran konvensional.

Tabel 4. Persentase Setiap Kategori Karakter Siswa

\begin{tabular}{lcc}
\hline \multirow{2}{*}{ Kategori } & \multicolumn{2}{c}{ Banyak Siswa (\%) } \\
\cline { 2 - 3 } & Kelas Eksperimen & Kelas Kontrol \\
\hline Sangat Baik & $8(28,57 \%)$ & $4(14,29 \%)$ \\
Baik & $20(71,43 \%)$ & $21(75,00 \%)$ \\
Cukup & 0 & $3(10,71 \%)$ \\
Kurang & 0 & 0 \\
Sangat Kurang & 0 & 0 \\
\hline
\end{tabular}

Hasil angket karakter siswa ditriangulasi dengan hasil analisis data wawancara karakter siswa dan lembar observasi karakter siswa. Triangulasi digunakan untuk mencocokkan antara data angket dengan data wawancara dan observasi. Rangkuman hasil triangulasi data karakter siswa disajikan pada Tabel 5.

Tabel 5. Triangulasi Data Karakter Siswa

\begin{tabular}{llll}
\hline \multirow{2}{*}{ Kelas } & \multicolumn{3}{c}{ Teknik } \\
\cline { 2 - 4 } & Wawancara & Observasi & Angket \\
\hline Eksperimen & Sesuai & Sesuai & Sesuai \\
Kontrol & Sesuai & Tidak Sesuai & Sesuai \\
\hline
\end{tabular}

Berdasarkan Tabel 5 dapat dilihat bahwa data karakter pada kelas eksperimen valid dan konsisten, sedangkan data karakter pada kelas kontrol terindikasi tidak valid dan tidak konsisten. Hal tersebut menunjukkan bahwa strategi pembelajaran REACT berorientasi kearifan lokal berdampak positif terhadap perkembangan karakter siswa.

\section{Pembahasan}

Strategi pembelajaran REACT merupakan salah satu strategi pembelajaran kontekstual yang memberikan ruang gerak dalam membangun pengetahuan. Pembelajaran kontekstual ini lebih menekankan pada strategi pembelajarannya dari pada hasil belajarnya, dengan harapan dari proses belajar tersebut siswa mampu mengkonstruksikan sendiri pengetahuan dan mengkomunikasikan berbagai ide dengan jelas. Hal tersebut menyebabkan 
siswa dapat meningkatkan kemampuan pemecahan masalah matematikanya. Temuan tersebut tentunya memperkuat temuan-temuan penelitian sebelumnya (misalnya: Hasanah et al., 2019; Marlissa \& Widjajanti, 2015; Putri \& Santosa, 2015) Strategi ini yang terdiri dari lima tahapan yaitu relating (mengaitkan), experiencing (mengalami), applying (menerapkan), cooperating (kerjasama) dan transferring (menggunakan pengetahuan dalam konteks baru atau situasi baru), jelas mampu meningkatkan peran aktif siswa selama proses pembelajaran.

Pengintegrasian nilai-nilai kearifan lokal digunakan sebagai sumber motivasi untuk membentuk dan menumbuhkan karakter positif pada siswa. Pada buku siswa dan LKS, nilai-nilai kearifan lokal tersebut dimunculkan sesuai dengan motivasi yang ingin disampaikan dan ketepatan penggunaannya dengan langkah-langkah pembelajaran. Sebagai contoh, pada bagian awal buku matematika (sebelum masuk pada paparan materi) dimunculkan kearifan lokal melalu slogan "puntul-puntul tiyuke yen sai sangihin pedas dadi mangan", dilengkapi dengan makna yang terkandung. Karakter yang ingin dibangun adalah agar siswa memiliki motivasi untuk terus belajar dan tertanam dalam dirinya suatu keyakinan bahwa kalau mereka tekun mempelajari sesuatu, maka mereka pasti bisa.

Tahapan-tahapan dalam proses penerapan strategi pembelajaran REACT berorientasi kearifan lokal, juga sangat mendukung kemampuan siswa menghadapi dan menyelesaikan masalah. Pada tahap awal mengaitkan (relating), pembelajaran dikaitkan dengan konteks yang nyata sambil menggali sejauh mana pengetahuan awal siswa mengenai materi yang akan dikaji. Pada langkah ini, siswa juga diberikan motivasi untuk melakukan kegiatan pembelajaran dengan mengintegrasikan nilai kearifan lokal "putul-putul tiuke gen sangih pedas dadi mangan" (setumpul-tumpulnya pisau kalau diasah pasti akan tajam).

Pada tahap mengalami (experiencing), persepsi siswa mengenai materi dapat diketahui. Siswa sendiri menyadari tentang hubungan materi yang dikaji dengan permasalahan terkait konsep tersebut. Penyelesaian permasalahan tersebut dilakukan dalam kelompok belajar. Guru memotivasi siswa untuk menerapkan prinsip hidup "jele melah gelahang bareng" (baik buruk kita tanggung bersama). Pada tahap menerapkan (applying), setelah siswa mendapatkan konsep tersebut, siswa dituntun untuk menerapkan konsep tersebut untuk mendapatkan pemahaman yang lebih mendalam dalam pembelajaran diskusi kelompok. Guru memberikan motivasi pada langkah ini dengan mengingatkan nilai "yeh ngetel mekelo-mekelo bisa molongin" (tetesan air lama-lama bisa melubangi batu), maknanya adalah jangan mudah putus asah, seberat apapun pekerjaan itu kalau dikerjakan dengan tekun akan menghasilkan sesuatu yang menakjubkan. Selanjutnya pada tahap kerjasama (cooperating), siswa dimungkinkan untuk melaksanakan kerjasama dan berkomunikasi dengan siswa lain dalam satu kelompok dalam menyelesaikan permasalahan yang diberikan untuk mendapatkan solusi yang tepat. Guru juga meminta siswa menerapkan prinsip hidup "apang sing gangsaran tindak kuangan daya" (jangan hanya cepat bertindak, tetapi tidak memikirkan apa yang dilakukan).

Pada tahap terakhir yaitu menggunakan pengetahuan dalam konteks baru atau situasi baru (transferring), siswa dituntun untuk mencoba menerapkan hasil yang telah diperoleh untuk menyelesaikan permasalahan dalam konteks yang baru dan melatih kemampuan berpikir siswa. Guru mengingatkan siswa pada prinsip hidup "siat-siat wayang pemuput mepunduh di gedongane" sehingga siswa termotivasi untuk belajar lebih giat lagi dan mempersiapkan diri lebih baik lagi. Dengan demikian siswa mampu memberdayakan kemampuan pemecahan masalah dengan menentukan metode yang dirasakan paling tepat dalam memahami materi pelajaran. Hal tersebut sesuai dengan pendapat Rusman (2010) yang menyatakan bahwa untuk memperkuat pengalaman belajar yang aplikatif bagi siswa, pembelajaran sebaiknya lebih banyak memberikan kesempatan bagi siswa untuk melakukan, mencoba dan mengalami sendiri. Hal senada juga disampaikan Crawford (2001), bahwa proses belajar akan berlangsung dengan baik ketika siswa memiliki kesempatan menyampaikan pendapat dan memperoleh timbal balik dari teman-temannya.

Dalam pelaksanaan pembelajaran berorientasi kearifan lokal juga berdampak pada karakter positif siswa. Dengan demikian, pelaksanaan pendidikan karakter dapat difasilitasi dengan menggunakan penerapan strategi pembelajaran REACT berorientasi kearifan lokal. Berdasarkan temuan-temuan kualitatif, dampak dari strategi pembelajaran REACT terhadap karakter siswa diantaranya: (1) meningkatnya hubungan siswa dengan Tuhan, sebagai contoh melaksanakan persembahyangan/berdoa sebelum pembelajaran dan tidak mengganggu teman lain saat sembahyangan; (2) rasa percaya diri siswa bertambah dikarenakan selalu bersyukur, mengingat apa yang dilakukan siswa adalah anugerah dari Tuhan, (3) meningkatkan hubungan siswa dengan siswa lainnya, dilihat dari bagaimana siswa saling membantu sama lainnya dalam menyelesaikan permasalahan yang diberikan ketika 
pembelajaran kelompok; dan (4) meningkatnya motivasi siswa dalam belajar dikarenakan siswa senang mendengarkan nilai-nilai kearifan lokal yang menjadikan perubahan sikap yang berdampak positif dalam proses pembelajaran.

\section{SIMPULAN}

Berdasarkan hasil penelitian dan pembahasan, diperoleh beberapa kesimpulan. Pertama, terdapat perbedaan signifikan kemampuan pemecahan masalah matematis antara siswa yang mengikuti pembelajaran dengan strategi pembelajaran REACT berorientasi kearifan lokal dan siswa yang mengikuti pembelajaran konvensional. Kedua, kemampuan pemecahan masalah matematis siswa yang mengikuti pembelajaran dengan strategi REACT berorientasi kearifan lokal lebih tinggi dari pada kemampuan pemecahan masalah matematika siswa yang mengikuti pembelajaran konvensional. Ketiga, karakter siswa berada pada kategori baik dan mengalami peningkatan ketika mengikuti pembelajaran dengan strategi pembelajaran REACT berorientasi kearifan lokal.

Berdasarkan temuan penelitian, kami merekomendasikan beberapa hal. Pertama, bagi para guru hendaknya mengintegrasikan kearifan lokal di daerahnya masing-masing dalam aktivitas pembelajaran, terutama untuk mendukung gerakan penguatan pendidikan karakter di Indonesia. Dalam pembelajaran matematika, kearifan lokal tersebut dapat dipadukan melalui strategi pembelajaran REACT. Kedua, nilai-nilai kearifan lokal yang diangkat dalam penelitian ini tidak semuanya mampu memfasilitasi penguatan pendidikan karakter siswa. Untuk itu diperlukan penelitian lainnya yang secara khusus melakukan investigasi terkait muatan karakter yang dapat dibangun dari nilai-nilai kearifan lokal yang ada di daerah lainnya. Ketiga, penelitian serupa, khususnya terkait penguatan pendidikan karakter dalam pembelajaran matematika masih perlu dilakukan. Untuk itu disarankan kepada peneliti lainnya yang memiliki minat terhadap topik tersebut, untuk melakukan penelitian pada topik tersebut dengan melibatkan populasi dan sampel yang lebih luas, sehingga memungkinkan generalisasi yang lebih luas.

\section{DAFTAR PUSTAKA}

American Association for the Advancement of Science (AAAS). (1990). Science for all Americans. New York, NY: Oxford University Press.

Badan Standar Nasional Pendidikan (BSNP). (2013). Buletin BSNP: Media komunikasi dan dialog standar pendidikan (Vol. VIII No. 2). Jakarta: Author. Retrieved from http://repositori.kemdikbud.go.id/316/1/Buletin-Edisi-12013.pdf

Budhayanti, C. I. S., Baskoro, J. T., Roostanto, E. A., Simanullang, B. (2008). Bahan ajar cetak: Pemecahan masalah matematika. Jakarta: Direktorat Jenderal Pendidikan Tinggi Departemen Pendidikan Nasional.

Candiasa, I. M. (2010). Pengujian instrumen penelitian disertasi aplikasi ITEMAN dan BIGSTEPS. Singaraja: Universitas Pendidikan Ganesha.

CORD. (1999). Teaching mathematics contextually. Waco, TX: CORD Communications. Retrieved from http://dl.icdst.org/pdfs/files/cf463a4e2f3afb0f7c94001fa54751d3.pdf

Crawford, M. L. (2001). Teaching contextually: Research, rationale, and techniques for improving student's motivation and achievement in mathematics and sciences. Waco, TX: CCI Publishing. Retrieved from https://dcmathpathways.org/sites/default/files/resources/2017-03/teaching_contextually.pdf

Creswell, J. W. (2010). Research design: Pendekatan kualitatif, kuantitatif dan mixed (A. Fawaid, Trans.). Yogyakarta: Pustaka Pelajar. (Original work published 2009)

Hasanah, N., Buchori, A., Prasetyowati, D., \& Nursyahidah, F. (2019). Efektivitas model pembelajaran Relating, Experiencing, Applying, Cooperating, Transferring (REACT) dan reciprocal teaching berbantuan game edukasi. Pythagoras: Jurnal Pendidikan Matematika, 14(1), 92 - 101. doi: https://doi.org/10.21831/pg.v14i1.17157

Hudojo, H. (2003). Pengembangan kurikulum dan pembelajaran matematika. Malang: IMSTEP.

James, K. (2015). Contextualized learning: What does the research data say? Intitute for Completion-Research Brief No. 1. Retrieved from https://www.citruscollege.edu/ifc/Documents/RB/11.2105RB.pdf 
Kawiyah, S. (2015). Pengembangan perangkat pembelajaran matematika berbasis saintifik untuk meningkatkan kemampuan pemecahan masalah dan prestasi belajar siswa. Pythagoras: Jurnal Pendidikan Matematika, 10(2), 201-210. doi: https://doi.org/10.21831/pg.v10i2.9163

Kemedikbud. (2017). Konsep dan pedoman penguatan pendidikan karakter. Jakarta: Kementerian Pendidikan dan Kebudayaan RI.

Kemendiknas. (2006). Peraturan Menteri Pendidikan Nasional Nomor 22 Tahun 2006 tentang Standar Isi.

Kemendiknas. (2010). Pengembangan pendidikan budaya dan karakter bangsa. Jakarta: Balitbang Kemendiknas.

Kostousov, S., \& Kudryavtsev, D. (2017). Towards a framework of using knowledge tools for teaching by solving problems in technology-enhanced learning environment. In J. M. Spector, D. Ifenthaler, D. G. Sampson, P. Isaias, \& L. Rodrigues (Eds.), 14th International Conference on Cognition and Exploratory Learning in the Digital Age, CELDA 2017 (pp. 246-250). Algarve: IADIS Press.

Lahinda, Y., \& Jailani, J. (2015). Analisis proses pemecahan masalah matematika siswa sekolah menengah pertama. Jurnal Riset Pendidikan Matematika, 2(1), 148 - 161. doi: https://doi.org/10.21831/jrpm.v2i1.7157

Marlissa, l., \& Widjajanti, D. B. (2015). Pengaruh strategi REACT ditinjau dari gaya kognitif terhadap kemampuan pemecahan masalah, prestasi belajar dan apresiasi siswa terhadap matematika. Jurnal Riset Pendidikan Matematika, 2(2), 186 -196. doi: https://doi.org/10.21831/jrpm.v2i2.7333

Miles, M, B., Huberman, A. M., \& Saldan, J. (2014). Qualitative data analysis: A methods sourcebook (3rd ed.). Thousand Oaks, CA: Sage Publication.

NCTM. (2000). Principle standards for school mathematics. Reston, VA: Author.

Pattaro, C. (2016). Character education: Themes and researches. An academic literature review. Italian Journal of Sociology of Education, 8(1), 6-30. doi: https://doi.org/10.14658/pupj-ijse-2016-1-2

Parwati, N. N. (2014). Pengintegrasian nilai kearifan lokal masyarakat Bali dalam model pembelajaran pemecahan masalah matematika untuk membangun karakter positif siswa SD di Kabupaten Buleleng. Singaraja: LPPPM Universitas Pendidikan Ganesha.

Presiden Republik Indonesia. (2017). Peraturan Presiden Republik Indonesia Nomor 87 Tahun 2017 tentang Penguatan Pendidikan Karakter.

Putri, M. E., Mardiyana, M., \& Saputro, D. R. S. (2019). The effect of application of REACT learning strategies on mathematics learning achievements: Empirical analysis on learning styles of junior high school students. International Journal of Educational Research Review, 4(2), 231-237. Retrieved from https://www.ijere.com/frontend//articles/pdf/v4i2/15pdf.pdf

Putri, R. I., \& Santosa, R. H. (2015). Keefektifan strategi REACT ditinjau dari prestasi belajar, kemampuan penyelesaian masalah, koneksi matematis, self-efficacy. Jurnal Riset Pendidikan Matematika, 2(2), 262 - 272. doi: https://doi.org/10.21831/jrpm.v2i2.7345

Republik Indonesia. (2003). Undang-Undang Republik Indonesia Nomor 20 Tahun 2003 tentang Sistem Pendidikan Nasional.

Rusman, R. (2010). Model-model pembelajaran. Jakarta: Grafindo Persada.

Samo, D. D. (2017). Kemampuan pemecahan masalah matematika mahasiswa tahun pertama dalam memecahkan masalah geometri konteks budaya. Jurnal Riset Pendidikan Matematika, 4(2), 141-152. doi: https://doi.org/10.21831/jrpm.v4i2.13470

Sanderse, W. (2013). The meaning of role modelling in moral and character education. Journal of Moral Education, 42(1), 28-42. doi: https://doi.org/10.1080/03057240.2012.690727

Sudiarta, I. B. P. (2006). Pengembangan model pembelajaran inovatif. Makalah disampaikan dalam Pendidikan dan Pelatihan MGMP Matematika SMK, Kabupaten Karangasem, Agustus 2010. 
PYTHAGORAS: Jurnal Pendidikan Matematika, 14 (2), 2019 - 187

Putu Agus Putra Wijaya, Gusti Ayu Mahayukti, I Nyoman Gita, Ni Nyoman Parwati

Sudiarta, I. B. P. (2008). Paradigma baru pembelajaran matematika membangun kompetensi berpikir kritis melalui pendekatan open-ended. Singaraja: Undiksha.

Sugiyono, S. (2017). Matode penelitian pendidikan (Pendekatan kuantitatif, kualitatif dan $R \& D$ ). Bandung: Alfabeta.

Suherman, E. (2003). Strategi pembelajaran matematika kontemporer. Bandung: Universitas Pendidikan Indonesia.

Ultay, E. (2012). Implementing REACT strategy in a context based physics class: Impulse and momentum example. Energy Education Science and Technology Part B: Social and Educational Studies, 4(1), 233-240.

Zurqoni, Z., Retnawati, H., Apino, E., \& Anazifa, R. D. (2018). Impact of character education implementation: A goalfree evaluation. Problems of Education in the 21st Century, 76(6), 881-899. Retrieved from http://oaji.net/articles/2017/457-1545497975.pdf

Zurqoni, Z., Retnawati, H., Arlinwibowo, J., \& Apino, E. (2018). Strategy and implementation of character education in senior high schools and vocational high schools. Journal of Social Studies Education Research, 9(3), 370-390. Retrieved from https://jsser.org/index.php/jsser/article/view/294 